\section{A patient's perspective}

I can't even remember exactly when my backaches started. It must have been about 20 years ago, when I was teaching kindergarten. That kind of work is hard on your back: everything happens close to the floor. I had a check-up with a specialist who, after taking x ray scans, told me that my back was weak. I understood that I needed to take better care of my back, so I went to a physiotherapist, who taught me some exercises to strengthen my back.

My backache comes and goes. I hardly ever see my general practitioner when the pain returns: I am convinced that the best way to get rid of back pain is to keep moving and to do my exercises. Recently my backache returned while I was making my grandchild's bed. I immediately started doing my exercises again as I fervently wanted to play in our local tennis competition, but I was afraid to move. So the pain got worse. My general practitioner told me to get going again, that turned out to be good advice.

I know that the best treatment for my backache is to do my exercises daily, even when my back is fine. But that is a hard advice to follow for a woman with an active life like mine.

Mrs Veenhof-Orvan, aged 61 years, Breille

and therapeutic interventions has now been incorporated in clinical guidelines. A few initial surveys have shown that these guidelines are being followed to some extent, but there is still room for improvement, especially in those countries and settings in which a large discrepancy exists between recommendations in guidelines and actual management in clinical practice. Measures should be taken to minimise this gap. Simply developing and publishing evidence based guidelines and subsequently disseminating these guidelines may not be effective enough to change practice. Implementation seems essential in changing clinical practice. Several trials have evaluated implementation of guidelines and its effect on patient and process outcomes..$^{25}$ w8 These trials show modest effects at best. More intensive multifaceted interventions might be needed to achieve further progress in this area.

We thank M A Pellikaan, a trainee general practitioner, for her help in getting the patients' stories.

Contributors: BWK wrote the first draft. MWvT and ST critically appraised and improved it.

Competing interests: None declared.

1 Cherkin DC, Deyo RA, Wheeler K, Ciol M. Physician variation in diagnostic testing for low back pain: who you see is what you get. Arthritis Rheum 1994;37:15-22.

2 Cherkin DC, Deyo RA, Loeser JD, Bush T, Waddell G. An international comparison of back surgery rates. Spine 1994;19:1201-6.

Van Tulder MW, Koes BW. Low back pain: acute. Clinical Evidence. London: BMJ Publishing Group, 2006.
4 Van Tulder MW, Koes BW. Low back pain: chronic. Clinical Evidence. London: BMJ Publishing Group, 2006.

5 Deyo RA, Rainville J, Kent DL. What can the history and physical examiDeyo RA, Rainville J, Kent DL. What can the history and ph
nation tell us about low back pain? JAMA 1992;268:760-5.

6 Pengel LHM, Herbert RD, Maher CG, Refshauge KM. Acute low back pain: a systematic review of its prognosis. BMJ 2003;327:323-5.

7 Croft PR, Macfarlane GJ, Papageorgiou AC, Thomas E, Silman AJ. Outcome of low back pain in general practice: a prospective study. $B M$ J 1998;316:1356-9.

8 Van den Hoogen HJ, Koes BW, van Eijk JT, Bouter LM, Deville W. On the course of low back pain in general practice: a one year follow up study. Ann Rheum Dis 1998:57:13-9.

9 Van den Hoogen HJ, Koes BW, Deville W, van Eijk JT, Bouter LM. The prognosis of low back pain in general practice. Spine 1997;22:1515-21.

10 Van Tulder MW, Assendelft WJ, Koes BW, Bouter LM. Spinal Van Tulder MW, Assendelft WJ, Koes BW, Bouter LM. Spinal
radiographic findings and nonspecific low back pain. A systematic review of observational studies. Spine 1997;22:427-34.

11 Roland M, van Tulder M. Should radiologists change the way they report plain radiography of the spine? Lancet 1998;352:348-9.

12 Jarvik JG, Deyo RA. Diagnostic evaluation of low back pain with emphasis on imaging. Ann Int Med 2002;137:586-97.

13 Pincus T, Burton AK, Vogel S, Field AP. A systematic review of psychological factors as predictors of chronicity/disability in prospective cohorts of low back pain. Spine 2002;27:E109-20.

14 Linton SJ, Hallden K. Can we screen for problematic back pain? A Linton SJ, Hallden K. Can we screen for problematic back pain? A
screening questionnaire for predicting outcome in acute and subacute back pain. Clin J Pain 1998;14:209-15.

15 Van Tulder MW, Koes B, Seitsalo S, Malmivaara A. Outcome of invasive treatment modalities on back pain and sciatica: an evidence-based review. Eur Spine J 2006;15:S82-92.

16 Koes BW. Surgery versus intensive rehabilitation programmes for chronic low back pain: spinal fusion surgery has only modest, if any, effects. BMJ 2005;330:1220-1.

17 Fairbank J, Frost H, Wilson-Macdonald J, Yu L-M, Barker K, Collins R, for the Spine Stabilisation Trial Group. The MRC spine stabilisation trial: a randomized controlled trial to compare surgical stabilisation of the lumbar spine with an intensive rehabilitation programme for patients with bar spine with an intensive rehabilitation prog
chronic low back pain. BMJ 2005;330:1233-9.

18 Fritzell P, Hagg O, Wessberg P, Nordwall A, the Swedish Lumbar Spine Study Group. 2001 Volvo award winner in Clinical studies: Lumbar fusion versus nonsurgical treatment for chronic low back pain. Spine 2001;26:2521-34.

19 Brox JI, Sorensen R, Friis A, Nygaard O, Indahl A, Keller A, et al Randomised clinical trial of lumbar instrumented fusion and cognitive intervention and exercises in patients with chronic low back pain and disc degeneration. Spine 2003;28:1913-21.

20 Jellema P, van der Windt DAWM, van der Horst HE, Twisk JWR, Stalman WAB, Bouter LM. Should treatment of (sub)acute low back pain be aimed at psychosocial prognostic factors? Cluster-randomised clinical trial in at psychosocial prognostic factors? Cl
general practice. BMI 2005;331:84-90.

21 Koes BW, van Tulder MW, Ostelo R, Burton AK, Waddell G. Clinical guidelines for the management of low back pain in primary care: an international comparison. Spine 2001;26:2504-13.

22 Airaksinen O, Brox JI, Cedrashi C, Hildebrandt J, Klaber-Moffet J, Kovacs F, et al, on behalf of the COST B13 Working Group on Guidelines for Chronic Low Back Pain. European guidelines for the management of chronic nonspecific low back pain. Eur Spine J 2006;15:s192-300.

23 Brennan GP, Fritz JM, Hunter SJ, Thackeray A, Delitto A, Erhard RE. Identifying subgroups of patients with acute/subacute "nonspecific" low Identifying subgroups of patients with acute/subacute "nonspecific" low
back pain: results of a randomized clinical trial. Spine 2006;31:623-31.

24 Childs JD, Fritz JM, Flynn TW, Irrgang JJ. Johnson KK, Majkowski GR, et al. A clinical prediction rule to identify patients with low back pain most likely to benefit from spinal manipulation: a validation study. Ann Intern Med 2004;141:920-8.

25 Engers AJ, Wensing M, van Tulder MW, Timmermans A, Oostendorp RA, Koes BW, et al. Implementation of the Dutch low back pain guideline for general practitioners: a cluster randomized controlled trial. Spine 2005;30:559-600

(Accepted 28 April 2006)

\title{
Walk the line
}

A recent outpatient giving a contorted and unclear history provided a challenge in determining the benefit he might have from surgery. My boss smartly and simply suggested we follow that age old practice to "take a walk."

I was reminded this Mother's Day how the simplest things can often tell us the answer to the question we should have asked.

Reel back four years to when I arrived at night to stay at my family house on an island. My parents, both in their 70s, had been working hard all day, one of them scaling trees, and unsurprisingly they looked tired. The next day I suggested a walk. Oddly it was met with a lack of enthusiasm. We started out along the flat coastal road, but 10 metres later, at the first hint of an incline, my normally fit mother stopped. In the sunlight her face was a sickeningly familiar shade of grey. In the ensuing discussion the history of severe chest pain the day before was revealed. Twenty minutes later the general practitioner's electrocardiograph confirmed the obvious, and one hour later we were in a helicopter. Too late for thrombolysis, the angiogram revealed there was nothing to be done.

How often would a short walk tell you something about a patient or a relative? How often do the complexities and availability of investigations distort us from the simplest course? Sometimes the more complex a problem the simpler the answer. Indeed the answer to the question may lie just a few strides away.

Michelle J Thompson specialist registrar in cardiothoracic surgery, New Royal Infirmary, Edinburgh (jeanie.thompson@tiscali.co.uk) 